\title{
Business Sustainability - A Study of Most Sustainable Corporations
}

\author{
Mahesh G. Dalvi (Corresponding author) \\ Research scholar, National Institute of Industrial Engineering (NITIE) \\ Vihar Lake Powai, Mumbai. 400087, India \\ Tel: 91-996-770-0776 E-mail: dalvi.mahesh@gmail.com
}

Dr. Anju Singh

Assistant Professor, National Institute of Industrial Engineering (NITIE)

Vihar Lake Powai, Mumbai. 400087, India

E-mail: dranjusingh@gmail.com

Dr. Paravastu Rambabu

Chief Executive Officer, RSM GC Advisory, Mumbai, India

E-mail: ram.babu@general-carbon.com

Dr. Nagesh N. Murthy

Academic Director, Center for Sustainable Business Practices

Charles Lundquist College of Business, University of Oregon, Eugene, USA

E-mail: nmurthy@uoregon.edu

Dr. Nachiket Gosavi

Assistant Professor - Economics, Sardar Patel Institute of Economics and Social Research

Ahmedabad, Gujrat, India

E-mail: nogochi@gmail.com

Received: March 23, 2019 Accepted: April 12, 2019 Published: May 16, 2019

doi:10.5296/emsd.v8i2.14790 URL: https://doi.org/10.5296/emsd.v8i2.14790 


\section{Abstract}

'G100' is the list of most sustainable 100 corporations out of thousands of global leading corporations. G100 corporations are acknowledged every year during the world economic forum. The focus of the study is to identify the key factors which support these corporations to get listed in G100 and to check the relationship of these factors with superior sustainability performance. Literature review enabled us to understand the different motives and factors influencing the drive of sustainability. These are categorized as operational and strategic drivers based on their nature. Multiple regression analysis carried out to check the correlation between the Sustainability drivers and, the repeat performance in G100 by these corporations.

Findings helped us conclude that Sustainability initiatives have a motive of an operational benefit and it is also considered as a strategic driver by adding social and environmental dimension in the core purpose of the organization. A positive correlation is confirmed between corporations adopting sustainability as a strategic driver and their performance in G100. Year on year continual improvement is observed in the average scores of G100 corporations and it confirms the contribution of global sustainability indices in helping overall sustainable development.

Proposed model adoption may help corporations to drive their sustainability programs and as a result, perform better in G100 with consistency. This study provides insights into sustainability champions and business leaders to understand the role of sustainability drivers. Business leaders can achieve superior sustainability performance in global sustainability indices using the findings of this study. It will also ensure the good governance of sustainability initiatives.

Keywords: Business sustainability, Sustainability drivers, Sustainability indices

\section{Introduction}

Rapid digitalization has transformed the role of the stakeholders in the business and it has become critical in the last two decades. Investors have become very important stakeholders. As a response to this change, 'Corporate Sustainability Report' a new practice has become popular to share the non-financial information by the leading public listed corporations. Due to the multidimensional nature of the information, it was not easy on the part of shareholders to evaluate the information. Global sustainability indices made it easy by publishing the ranks of the global leading corporations based on their sustainability performance. One such leading global sustainability index is G100 'The Global 100 Most Sustainable Corporations', declared every year during 'World Economic Forum' Davos.

Development of the guidelines standardized this information and it has now become a structured report termed as sustainability report. Sustainability report addresses multidimensional performance measures along with business risks and mitigation strategies. Due to its multidimensional nature, investors find it difficult to assess it. To help investors, Global sustainability indices rank the global leading corporations based on their sustainability performance. G100 corporations' sustainability initiatives are driven by various internal or external factors; which are either operational in nature or strategic by intent. 
In this study, the term sustainability driver is used for operational or strategic factors. For this study, the data of G100 corporations from 2005 to 2015 is received from Corporate Knights Magazine. For operational drivers, the significance is checked by multiple regression analysis between the secondary data of G100 key performance indicators (KPI) and respective G100 scores. For strategic drivers, content analysis was carried out and measured by developing suitable scales. Three consecutive years $(2013,2014,2015)$ data were considered for checking the statistical inference of sustainability drivers with sustainability performance. Multiple regression analysis was carried out between G100 scores and G100 KPIs. Stepwise elimination of least significant KPI gave us the most significant KPI for further analysis.

Sustainability reports of the G100 corporations were studied with the content analysis for strategic sustainability drivers and a suitable scale was developed to evaluate respective data. Multiple regression analysis was carried out between the superior sustainability performance and the content of strategic drivers of sustainability. Regression equation fitted the graphs plotted for all three years and Z-test was conducted to validate the results. Findings of the research will enable business leadership or chief sustainability officers to apply this approach in their sustainability program and align their sustainability initiatives to achieve superior sustainability performance in global sustainability indices.

\section{Literature Review}

At the beginning of the 17th Century, with the advent of industrialization era, mechanization enabled the industrialist to produce large quantities and trade them across different geographies using different modes of transport (Bhattacharya et al., 2009). As a result, business houses become powerhouses but it also caused an imbalance in the ecosystem, depletion of natural resources and severe environmental impacts like climate change (United Nations, 2013, Stern, 2015). In addition to the environmental challenges, social challenges like economic disparity and low level of trust have also become common among the stakeholders. As a response to these external changes, public listed corporations started a multidimensional disclosure to their stakeholders. Over the years, global guidelines converted these disclosures into a structured report called 'Corporate Sustainability Report' (Okumus and Edelman, 2015).

Corporate sustainability is described as a long term strategic approach by corporations; consider themselves responsible for reversing the trends of their negative impacts and making societal contributions and creating stakeholder value (Stuart Hart, 2003). RobecoSam (Sustainable Asset Management) defined corporate sustainability as a business approach for creating long-term shareholder value by embracing opportunities and managing risks deriving from economic, environmental and social developments (ROBECOSAM 2006). Leading corporations welcomed the standard frameworks and The United Nations Environment Program (UNEP), and the Coalition for Environmentally Responsible Economics (CERES) encouraged the use of standards to publish a sustainability report. This widely used voluntary framework of sustainability reporting is known as the Global Reporting Initiative (GRI). The Sustainability Accounting Standards Board (SASB), Accountability Standard AA1000 and Social Responsibility standard ISO 26000 have also developed the standards (Siew et al., 
2014).

Initially, sustainability programs are considered only environmental or social improvement programs however a rising demand by investors has forced corporations to integrate it and to keep the investors updated about the business practices, and associated risks (Coburn et al., 2011). Studies revealed that corporations with sustainability reports have a competitive advantage, comparatively lower share price volatility, better reputation, and brand image. Therefore, many global leading corporations adopted the practice of publishing their corporate sustainability reports. This helped corporations to prepare themselves to remain future ready for any external environment changes (Siew et. al.2014). Impacts of industrialization highlighted emissions due to operations and products; however, many other impacts like land use pattern, etc. are not highlighted (Andy Skuce, 2014). Initial adoption to business sustainability initiatives was due to external forces like policy changes, and regulatory norms changes (Gibson, 2012).

Over the years, corporations started reporting extra benefits like resource efficiency, cost savings, and culture of innovation and attractiveness among the stakeholders. Expectations of society from the business changed and today business is expected to serve the needs of society while making the profits (Regina Scheyvens et.al. 2016). World happiness report addresses issues like social imbalance; need to practice humanity, and measuring SDGs. It mentions about fulfilling our deepest needs without harnessing material life. Overall business houses in the future are expected to generate social and environmental value and contribute by their business transformation (John Helliwell et.al. 2012). Evaluation of sustainability is a complex process due to its multidimensional nature and investors often find it difficult to analyze it. The future roadmap of sustainability initiatives enables corporations to track their sustainability performance and helps the alignment of stakeholders (O'Riordan and Fairbrass, 2008, Gibson, 2012).

How business leadership encourages continual improvement in their sustainability performance is a major challenge in front of global leading listed corporations (Piketty, 2014). Most of the leading corporations follow stakeholder wise value creation and measure the impact of sustainability initiatives (Lopez et al., 2007). Organization vision and mission statements represent value creation with the various business stakeholders (Stubbs and Cocklin, 2008). Well defined vision/mission statement provides a solid foundation for the organization's long-term strategy and creates a positive impact on the stakeholders (Joseph and Taplin, 2011). Stakeholder's issues prioritization is done by a materiality matrix exercise (Osterwalder and Pigneur, 2010, Zott and Amit, 2011, Chia-Wei Hsu 2013). Such a matrix helps to create factors for long term roadmap. Creating a strategic sustainability roadmap not only gives a competitive advantage but also supports better economic performance (Porter and Krammer 2006, Peters and Zelewski, 2013, Stead and Stead, 2013).

Complex nature of the data in the sustainability report was a major challenge for the investors to assess the sustainability performance of the corporation and to make the investment decision. Global sustainability indices solved this difficulty by ranking global leading corporations according to their sustainability performance. Dow Jones Sustainability Indices 
(DJSI) is one such leading global sustainability index managed by RobecoSAM (Sustainability Asset Management). It evaluates corporations based on the criteria like good governance, risk management, stakeholder management, operational resource efficiency, and environmental management system. DJSI also tracks the corporation's external media performance using media stakeholder analysis (MSA). Every year Carbon Disclosure Project (CDP) sends a request to thousands of global corporations for their information on climate change, water, forests and publishes a report based on their performance. London Stock Exchange Group initiated the Financial Times Stock Exchange (FTSE) 4GOOD index series to measure the performance of corporations demonstrating strong environmental, social performance. Happy Planet Index (HPI) ranks countries according to their sustainability performance and aggregates information on human well-being. Many governments are finding it useful (Helliwell et al., 2015).

Corporate Knights magazine publishes one such global sustainability index known as Global most sustainable corporations (G100). Leading global corporations undergo five-level screening and evaluated for their performance across twelve tangible KPIs like the productivity of energy, carbon, water, waste, innovation capacity, percentage tax paid, pension fund status, CEO to average worker pay, employee turnover, leadership diversity, safety performance and performance pay link to clean capitalism. G100 revised its evaluation process in the year 2013 and it has been rated as the top sustainability index in the year 2016 (CSRHUB, 2016). G100 corporations are acknowledged every year at the World Economic Forum, Davos. The G100 index is considered to be one of the most consistent indices with the highest rating. (Corporate Knights Magazine).

The sustainable business model approach addresses social and environmental value creation and enables consistent sustainability ((Ehrenfeld and Hoffman, 2013). Out of thousands of global corporations, very few are listed in global sustainability indices. Sustainability reporting guidelines have ensured standardization in the framework of reporting hence it is interesting to study the parameters according to their significance and impacting corporation's sustainability performance (Bocken et. al., 2014). Operational benefits like cost reduction, innovation, resource efficiency are useful to the corporation (Baurngartner and Ebner, 2010). Driving factors of sustainability like legal compliance and external pressures of the supply chain act as a trigger; however, it will be rarely an area in which corporations enjoy strategic competence (Schaltegger, 2011).

From the literature, it is evident that sustainability programs are mainly considered improvement programs of the environmental and social dimension in addition to the economic dimension. Literature also takes our attention toward internal strategic factors contributing to the superior sustainability performance of global most sustainable corporations. With this study, we examine the significance of internal strategic factors and we termed these factors as sustainability drivers. 


\section{Macrothink

\section{Research Need, Objective, Scope and Methodology}

\subsection{Need, Objective of the Research}

The concept 'Business Sustainability' and 'Sustainability Performance' mainly evolved in the last two decades. Sustainability leaders, CEO's and Business leaders manage internal sustainability performance, whereas investors are interested in the external sustainability performance like getting listed in the global sustainability indices. Hence it is a topic of curiosity to understand the relationship between these internal and external measures of sustainability performance. In this study, the internal and external forces influencing corporation's sustainability initiatives are termed as sustainability drivers.

The implication of the study will be of value to the corporations to improve their sustainability performance and to get listed in the global sustainability indices like G100. It will also guide them on 'How to adopt the business model approach for business sustainability'. G100 index initiated in the year 2005 and in the year 2013, G100 revised sector's categorization. No other research study was observed based on the corporations listed in G100. The objective of this study is to identify the driving forces of sustainability and check their relationship with continual superior sustainability performance.

\subsection{Scope of Research}

Corporate sustainability reports cover multiple parameters across all the functions and improvement in each will surely improve overall performance; however, the purpose of this study is to identify the most significant parameters called the drivers of sustainability. Corporations' performance in the global sustainability indices and its frequency to get listed are considered as measures of sustainability performance in this study. Based on the findings of the literature review, parameters influencing sustainability performance (sustainability drivers) are categorized as either operational or strategic. Based on the boundary of control the parameters are categorized as internal or external, as shown in Figure 1. 


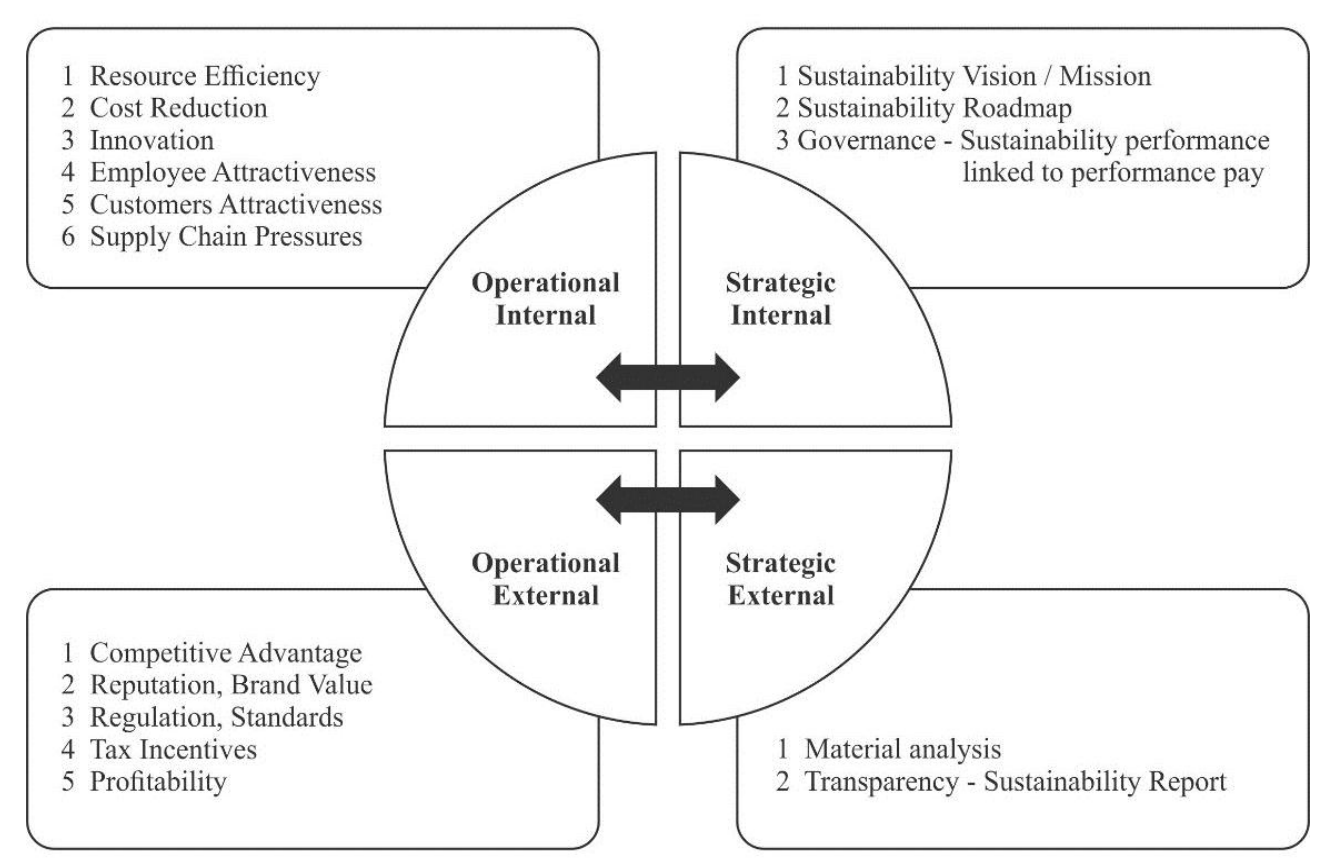

Figure 1. Driving forces for sustainability initiatives

\subsection{Research Methodology}

Literature review enabled us to build the conceptual framework for this study. List of G100 corporations and respective evaluation data from the year 2005 to 2015 received from the magazine Corporate Knights was analyzed. To minimize the variation, data of three consecutive years - 2013, 2014, and 2015 is considered in the statistical analysis. Multiple regression analysis was carried out between G100 scores and respective key performance measures of G100. Stepwise elimination of not so significant factors carried out to reach significant factors among G100.

G100 sustainability KPIs were considered significant operational drivers of sustainability in this study. Content analysis of the sustainability report was carried out for strategic drivers. With a suitable scale content analysis data, is made comparable and measurable. The business model approach enables continual superior performance hence multiple regression analysis is carried out between data of sustainability drivers and frequency of superior sustainability performance as shown in figure 2 . 


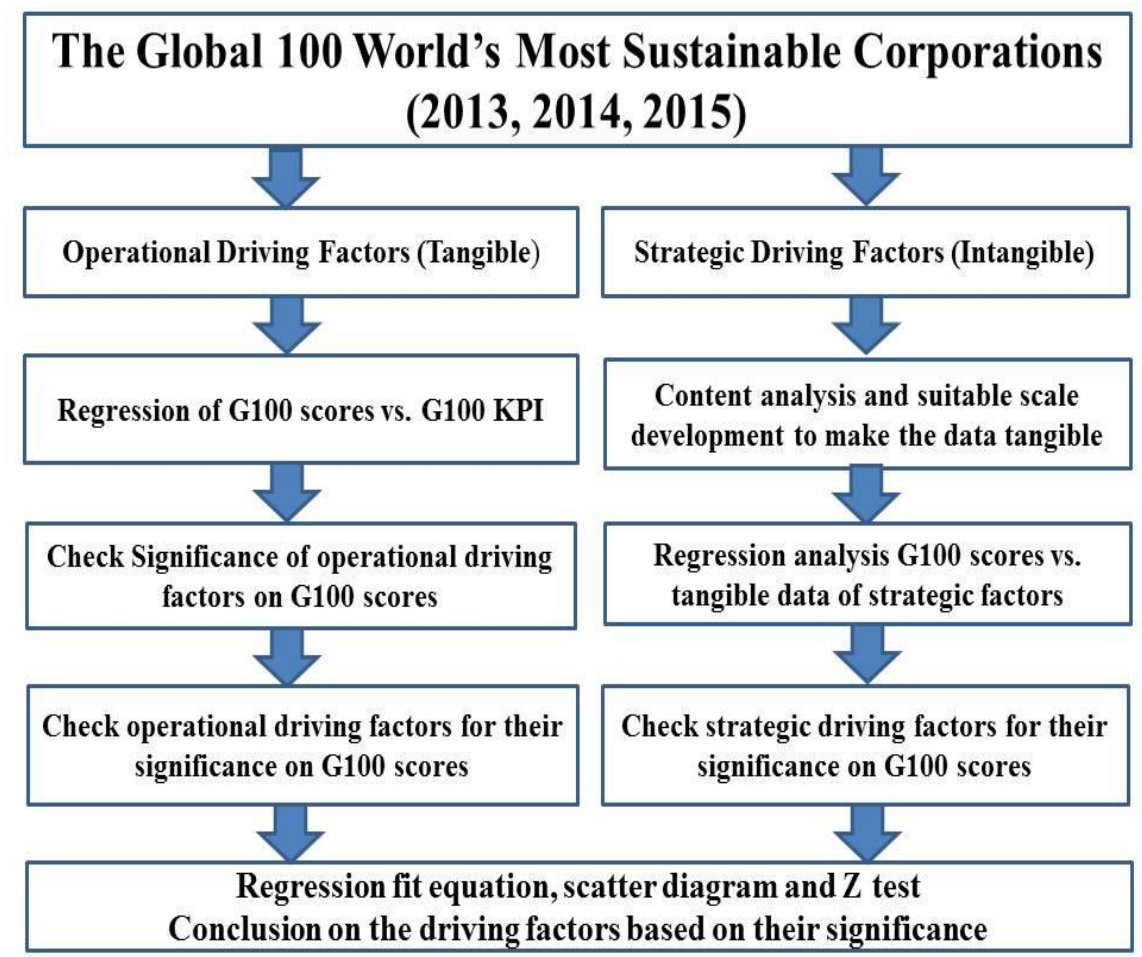

Figure 2. The flow of research methodology

Research is designed to check the superior sustainability performance of G100 corporations by the content analysis of

1. Social and environmental issues in the sustainability vision/mission statement

2. Social and environmental goals to be achieved in the form of sustainability roadmap

3. Sustainability report published with a defined scope of operations and products

4. Sustainability performance linked with the performance pay of the executives

Sustainability report's content analysis was carried out with the scale as mentioned in Table 4. Strategic sustainability drivers were considered as independent variables such as V1, V2, V3, and V4. The frequency of getting listed in G100 is considered as a dependent variable as a measure of the consistency of superior sustainability performance ' $\mathrm{V}$ ' shown in Figure 3. 


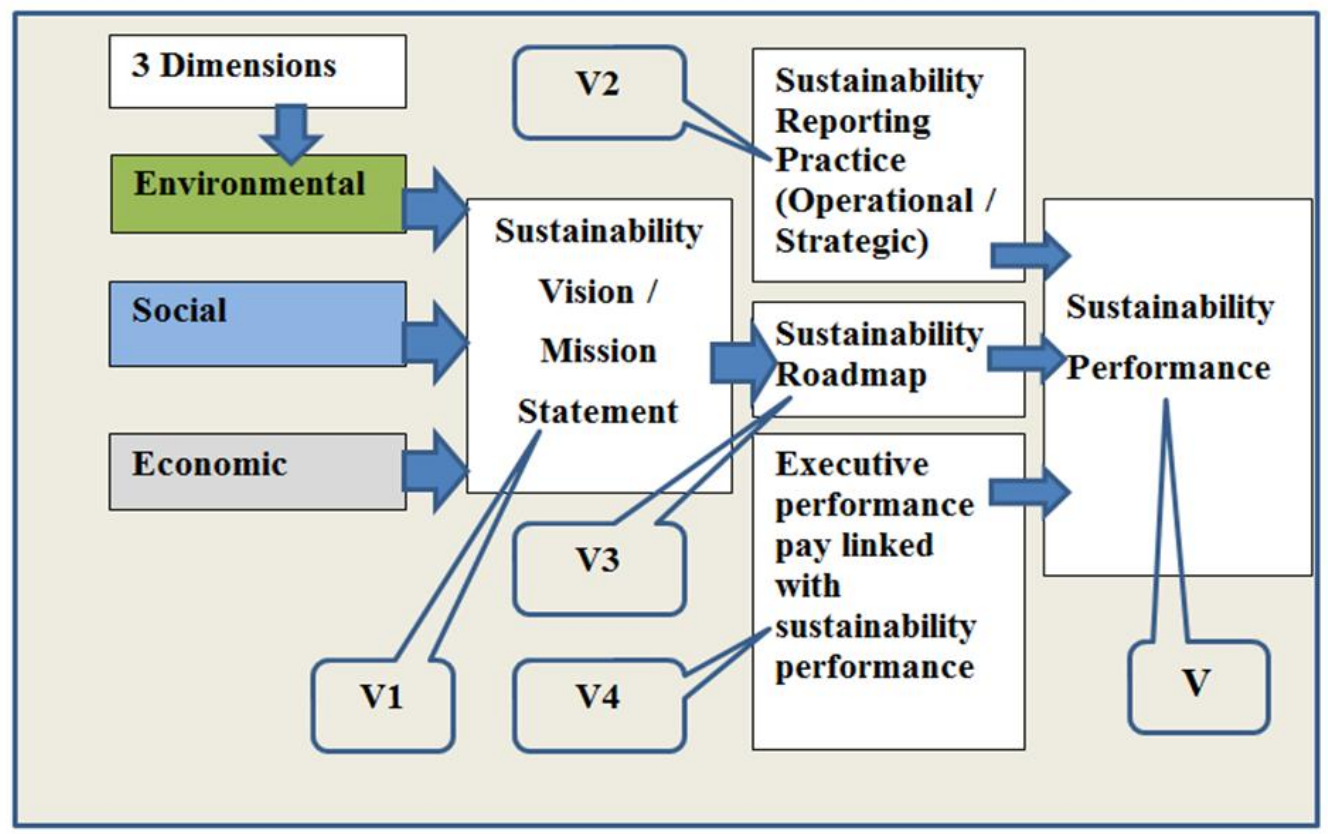

Figure 3. The framework used to check the content analysis

Strategic information of sustainability reports is studied like CEO statements, sustainability leader statements and strategy documents. Content analysis exercise was carried out by developing a suitable scale for internal drivers of sustainability like Sustainability Vision or Mission statement, Sustainability Roadmap, Materiality Matrix, etc. as shown in Table 1.

Table 1. Scale development for strategic drivers $(2013,2014,2015)$

\begin{tabular}{|c|c|c|c|c|c|}
\hline \multirow[t]{2}{*}{$\mathrm{Sr}$} & \multirow[t]{2}{*}{ Independent variables } & \multirow[t]{2}{*}{ Measure } & \multicolumn{3}{|c|}{ Measurement Scale } \\
\hline & & & 0 & 0.5 & 1.0 \\
\hline 1 & $\begin{array}{l}\text { Vision/Mission } \\
\text { statement }\end{array}$ & $\begin{array}{l}\text { The content of the } \\
\text { statement }\end{array}$ & $\begin{array}{l}\text { Does not } \\
\text { address }\end{array}$ & $\begin{array}{l}\text { Addresses social } \\
\text { or/and environment }\end{array}$ & $\begin{array}{l}\text { Addresses social } \\
\text { and environment }\end{array}$ \\
\hline 2 & Sustainability Roadmap & $\begin{array}{l}\text { Addresses future } \\
\text { goals }\end{array}$ & $\begin{array}{l}\text { Does not } \\
\text { address }\end{array}$ & $\begin{array}{l}\text { Performance } \\
\text { without future goals }\end{array}$ & $\begin{array}{l}\text { Performance with } \\
\text { future goals }\end{array}$ \\
\hline 3 & Materiality Matrix & $\begin{array}{l}\text { Addresses } \\
\text { Materiality }\end{array}$ & $\begin{array}{l}\text { Does not } \\
\text { address }\end{array}$ & - & $\begin{array}{l}\text { Materiality } \\
\text { addressed }\end{array}$ \\
\hline 4 & $\begin{array}{l}\text { Linkage with } \\
\text { performance pay of } \\
\text { executive }\end{array}$ & $\begin{array}{l}\text { KPI scores received } \\
\text { from Corporate } \\
\text { Knights }\end{array}$ & $\begin{array}{l}\text { Does not } \\
\text { address }\end{array}$ & $\begin{array}{l}\text { Linkage addressed } \\
\text { but not established }\end{array}$ & $\begin{array}{l}\text { Linkage and } \\
\text { process established }\end{array}$ \\
\hline 5 & Sustainability Initiatives & $\begin{array}{l}\text { Name of the } \\
\text { Initiative }\end{array}$ & $\begin{array}{l}\text { Does not } \\
\text { address }\end{array}$ & - & $\begin{array}{l}\text { Addressed with } \\
\text { goals/ measures }\end{array}$ \\
\hline
\end{tabular}

\section{Results and Discussion}

\subsection{General G100 (2005 to 2015)}

Corporations listed in G100 over 11 years, from the year 2005 to 2015 is a sample of 1100 corporations, however many corporations are listed more than once and the actual sample size is 357 corporations. Five corporations are listed for all 11 years, 122 corporations listed 


\section{Macrothink}

Environmental Management and Sustainable Development

ISSN 2164-7682

2019, Vol. 8, No. 2

only once in these 11 years and frequency corporations of getting listed is shown in figure.4

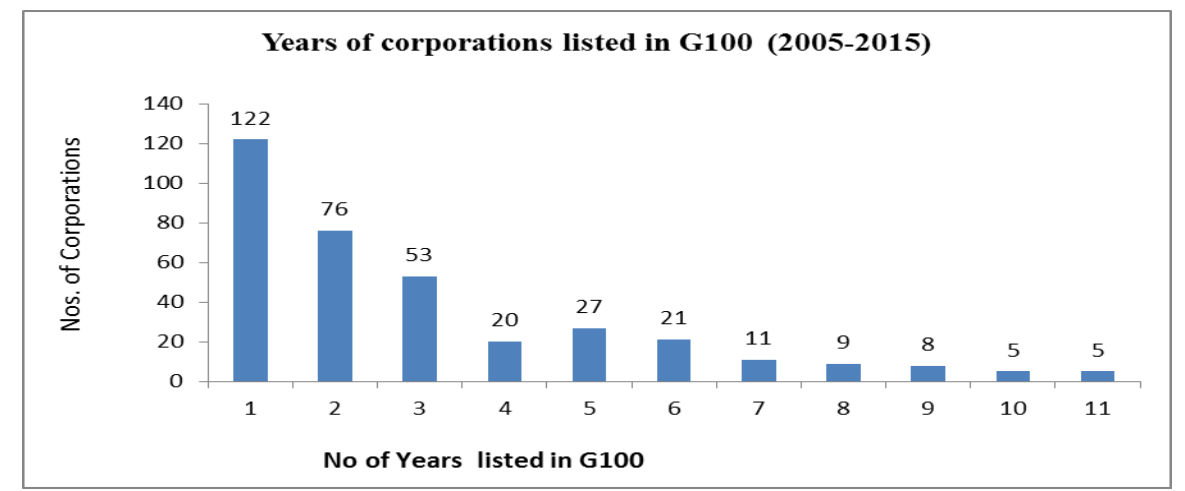

Figure 4. Frequency of getting listed in G100 (2005-2015)

More and more corporations are coming forward to disclose their sustainability data and information and publish their sustainability report. More than $90 \%$ of corporations listed in G100 post year 2012 publish their sustainability report. Sustainability report availability improved from 54\% in the year 2005 to $94 \%$ in the year 2015 as shown in Figure 5.

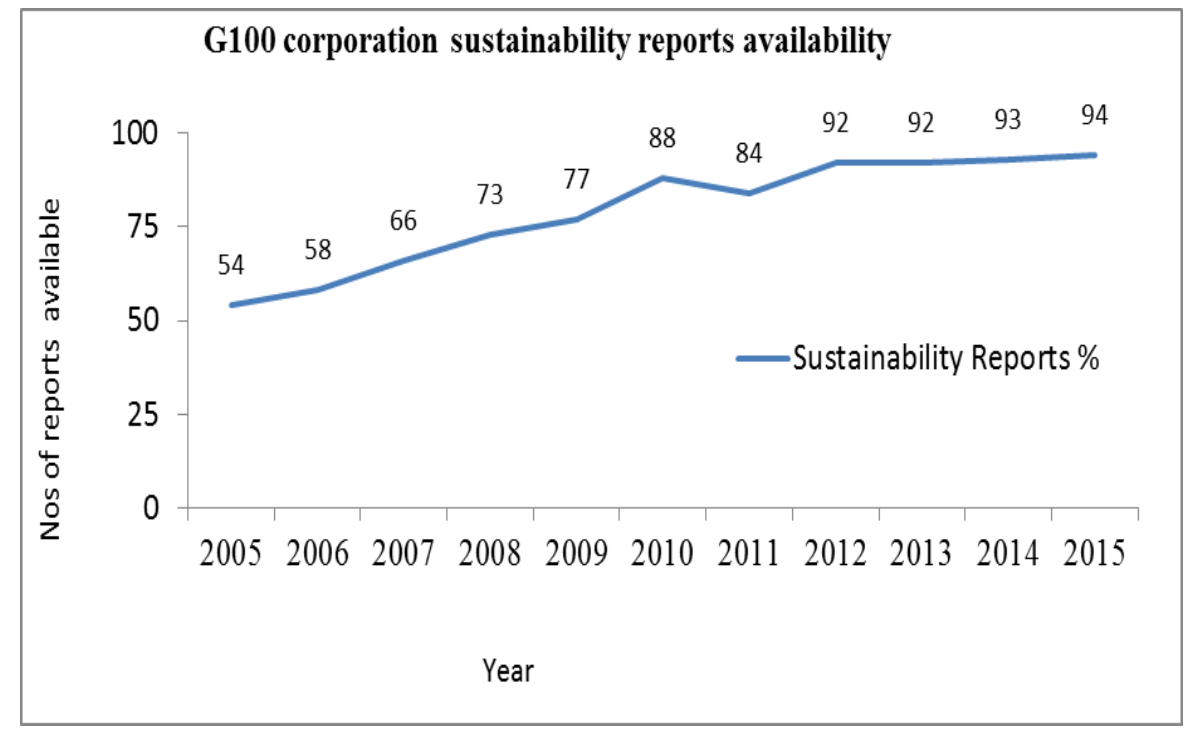

Figure 5. Availability of sustainability reports of G100 corporations

\section{$4.2 \operatorname{G100}(2013,2014,2015)$}

Corporations listed in G100 over three years 2013,2014, 2015 is a sample of 300 corporations and few corporations are listed repeatedly hence actual sample size is 151 corporations as shown in Figure 6 


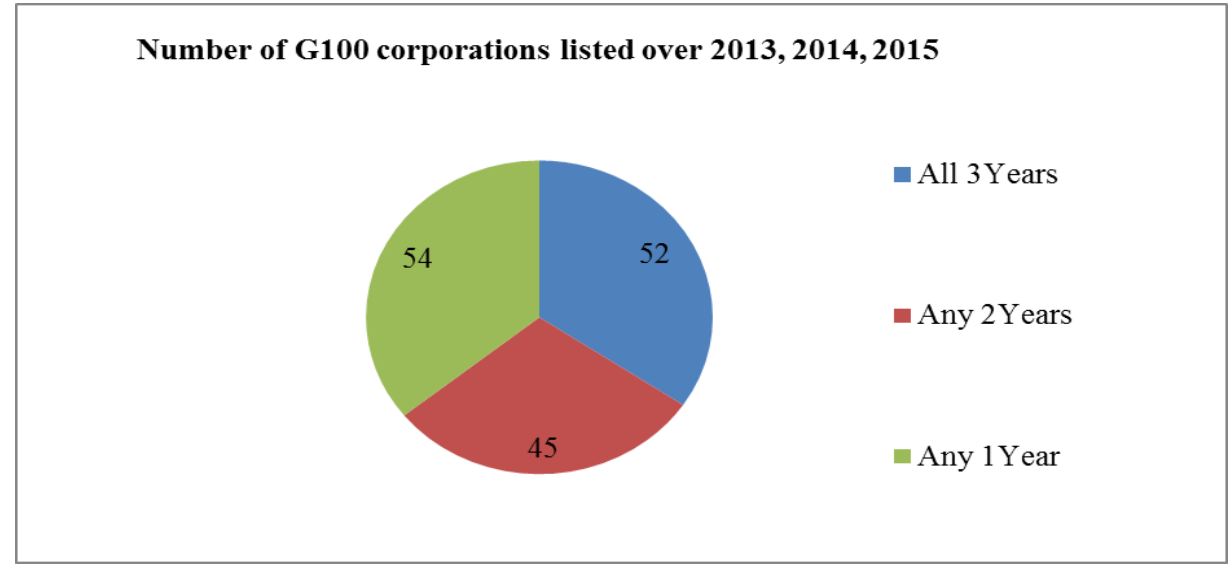

Figure 6. Frequency of getting listed in G100 (2013, 2014, 2015)

G100 corporations listed for years 2013, 2014, 2015 studied in detail and pie chart depicts sector-wise contribution across nine different sectors for this period. The materials, metals and chemicals, the energy, oil and gas, and the automobile sectors, which are carbon-intensive corporations, contribute to $20 \%$ of the G100 corporations as shown in Figure 7.

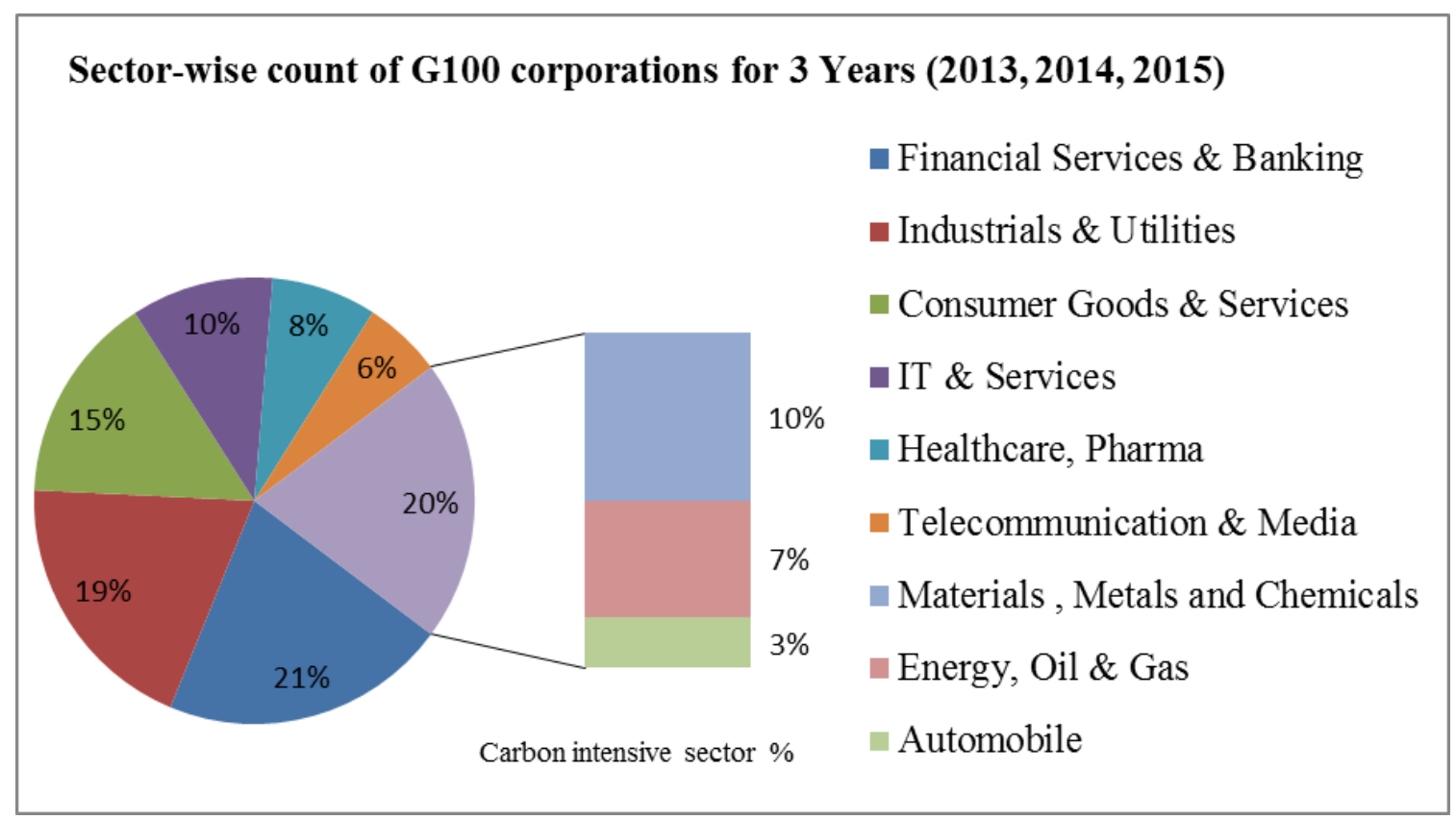

Figure 7. Sector-wise count of G100 corporations and carbon-intensive sectors

The various sustainability guidelines mentioned in the corporate sustainability reports of 100 corporations were studied and mapped. For the period studied total $91 \%$ of corporations follow GRI guidelines, $14 \%$ consider the AA1000 accountability standards, $7 \%$ refers to ISO 26000 and 7\% follow the Integrated report guidelines as shown in Figure 8. 


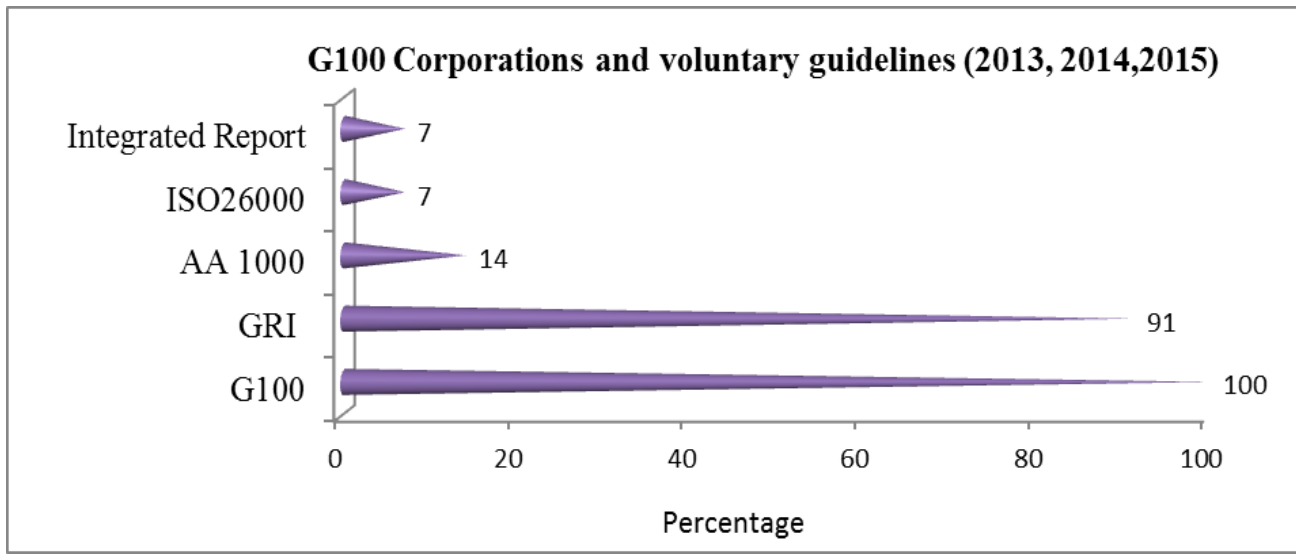

Figure 8. Sustainability Reporting Guidelines used by leading global companies

The percentage of the Global 100 Corporations listed in other indices was mapped and it was found that nearly $79 \%$ corporations were listed in CDP index, $71 \%$ were listed in DJSI World Index and 54\% were listed in the FTSE4GOOD index as shown in Figure 9.

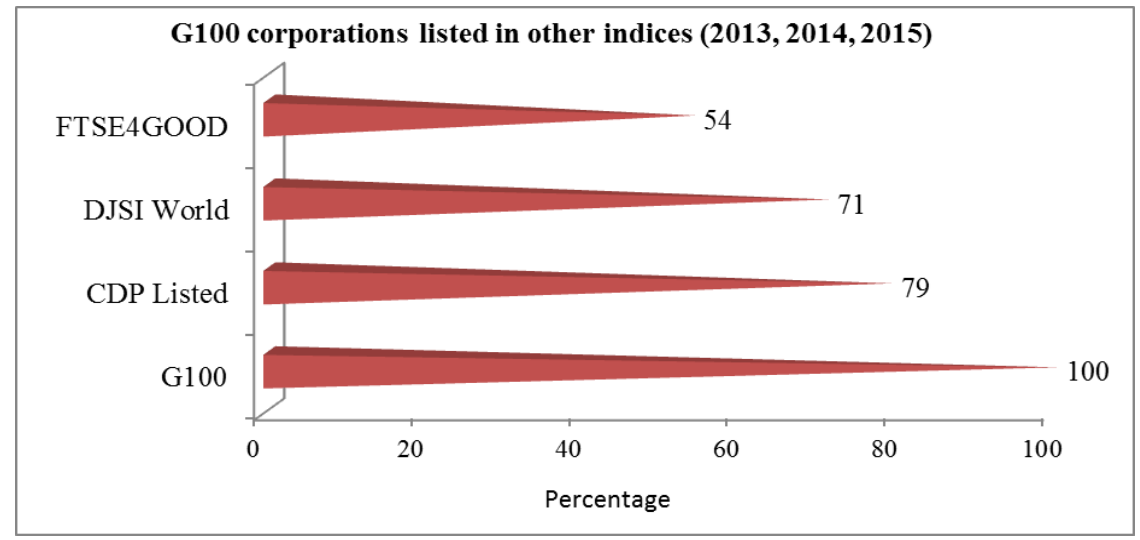

Figure 9. Sustainability report standards/ guidelines by G100 corporations

\subsection{Regression Analysis of G100 Scores vs. Sustainability KPI (2013, 2014, 2015)}

Multiple regression analysis carried out between G100 scores vs. G100 KPIs which we received from Corporate Knights and stepwise elimination carried out to find the most significant one as seen in table2.

Table 2. Result of regression analysis of G100 scores vs. G100 KPIs

\begin{tabular}{|l|l|l|l|l|l|}
\hline Dimension & G100 KPI & Unit of measure & 2013 & 2014 & 2015 \\
\hline $\begin{array}{l}\text { Resource } \\
\text { Management }\end{array}$ & $\begin{array}{l}\text { Energy } \\
\text { Productivity }\end{array}$ & Revenue / Energy Used & & & \\
\cline { 2 - 6 } & $\begin{array}{l}\text { Carbon } \\
\text { Productivity }\end{array}$ & Revenue / GHG emitted & & & \\
\cline { 2 - 6 } & $\begin{array}{l}\text { Water } \\
\text { Productivity }\end{array}$ & Revenue / Water withdrawal & & & \\
\cline { 2 - 6 } & $\begin{array}{l}\text { Waste } \\
\text { Productivity }\end{array}$ & Revenue / Waste Generated & & & \\
\hline $\begin{array}{l}\text { Financial } \\
\text { Management }\end{array}$ & $\begin{array}{l}\text { Innovation } \\
\text { Capacity }\end{array}$ & R\&D Expenses / Revenue & Significant & Significant & \\
\hline
\end{tabular}




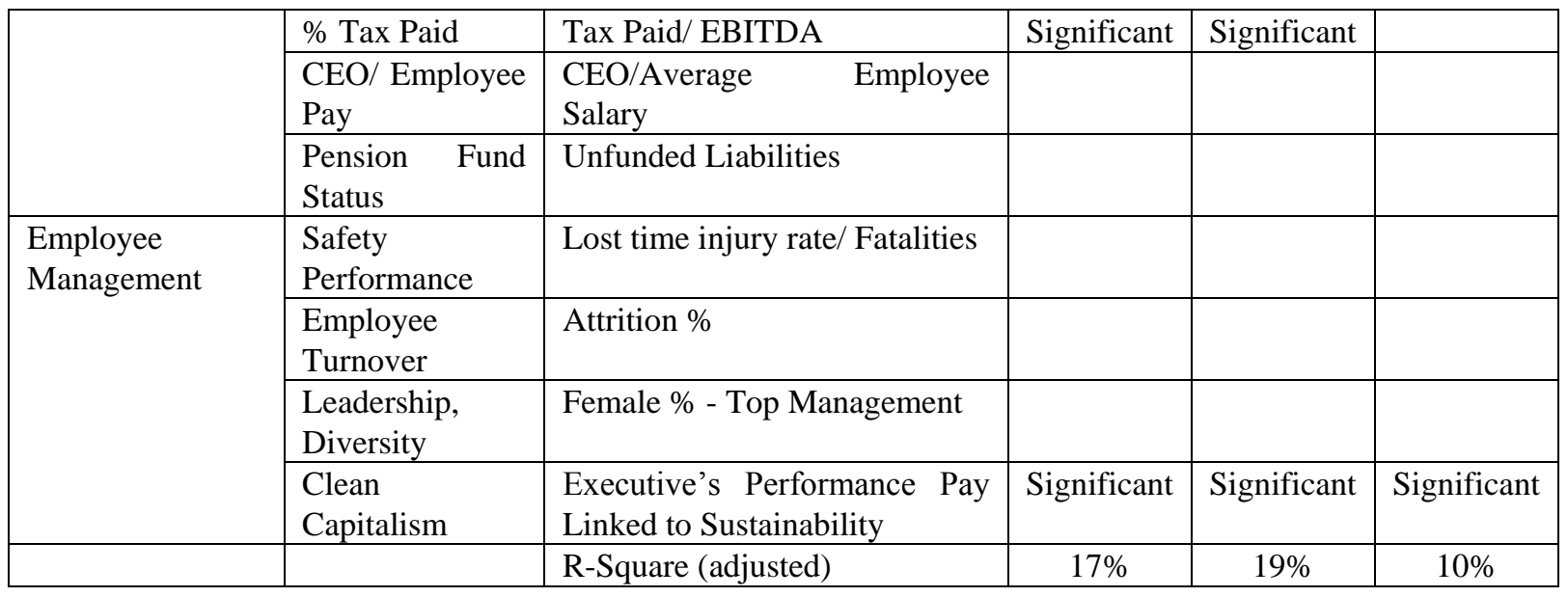

All the G100 corporations do mention their main focus as resource management, employee management and as a result, there is no significant difference due to these parameters. In the year 2013 and 2014, investment in research and development, and the percentage of tax paid were significant due to the growth within healthcare corporations as well as in the number of corporations and its' not so significant in the year 2015. Executive Compensation link to Sustainability Performance' sustained its very significance at a $99 \%$ confidence interval for all three years as seen in Table 2. Hence it is considered in the regression analysis G100 scores vs. sustainability data mapped from sustainability reports.

\subsection{Regression Analysis}

The Global 100 Scores and Independent Variable Multiple regression analysis carried out between G100 repeat performance and G100 corporation strategic driver's content analysis as presented in Table 3.

Table 3. Regression analysis results of G100 and content analysis (2013, 2014, and 2015)

\begin{tabular}{|c|c|c|c|c|c|}
\hline Predictors & Year & Coefficient & SE. Coefficient & $\mathrm{T}$ & $\mathrm{P}$ \\
\hline \multirow{3}{*}{ Intercept } & 2013 & 0.40098 & 0.02107 & 19.03 & 0 \\
\hline & 2014 & 0.42954 & 0.02063 & 20.82 & 0 \\
\hline & 2015 & 0.4848 & 0.01814 & 26.73 & 0 \\
\hline \multirow{3}{*}{ Sustainability Vision, Mission Statement } & 2013 & 0.06837 & 0.02351 & 2.91 & 0.005 \\
\hline & 2014 & 0.04305 & 0.02248 & 1.92 & 0.059 \\
\hline & 2015 & 0.04765 & 0.01965 & 2.43 & 0.017 \\
\hline \multirow{3}{*}{ Sustainability Roadmap } & 2013 & 0.04444 & 0.01986 & 2.24 & 0.028 \\
\hline & 2014 & 0.04556 & 0.01985 & 2.29 & 0.024 \\
\hline & 2015 & 0.02727 & 0.01406 & 1.94 & 0.056 \\
\hline \multirow{3}{*}{ Materiality } & 2013 & 0.02974 & 0.01303 & 2.28 & 0.025 \\
\hline & 2014 & 0.04239 & 0.01272 & 3.33 & 0.001 \\
\hline & 2015 & 0.03832 & 0.01046 & 3.66 & 0 \\
\hline \multirow{3}{*}{ Clean Capitalism } & 2013 & 0.02899 & 0.01678 & 1.73 & 0.087 \\
\hline & 2014 & 0.03569 & 0.01741 & 2.05 & 0.043 \\
\hline & 2015 & 0.02724 & 0.01366 & 1.99 & 0.049 \\
\hline \multirow{3}{*}{ Sustainability Report 'Nos. of Years Reported' } & 2013 & 0.012742 & 0.003702 & 3.44 & 0.001 \\
\hline & 2014 & 0.011787 & 0.003371 & 3.5 & 0.001 \\
\hline & 2015 & 0.006694 & 0.002734 & 2.45 & 0.016 \\
\hline$S$ & 2013 & 0.05981 & & & \\
\hline
\end{tabular}




\begin{tabular}{|l|l|l|}
\cline { 2 - 3 } & 2014 & 0.05794 \\
\cline { 2 - 3 } R-Square (adjusted) & 2015 & 0.04806 \\
\hline \multirow{4}{*}{ Analysis of Variance F-Value } & 2013 & $40.10 \%$ \\
\cline { 2 - 3 } & 2014 & $41.20 \%$ \\
\cline { 2 - 3 } & 2015 & $34.20 \%$ \\
\hline & 2013 & 14.28 \\
\cline { 2 - 3 } & 2014 & 14.86 \\
\cline { 2 - 3 } & 2015 & 11.29 \\
\hline
\end{tabular}

The steady growth of $8-10 \%$ in the intercept coefficient indicates that the overall sustainability performance of the G100 corporations is improving year on year raising its average performance. All three years, the $\mathrm{T}$ and $\mathrm{P}$ values for the sustainability vision, mission statement, sustainability roadmap, and materiality matrix are significant at a $99 \%$ confidence interval. The significance of materiality is growing an it indicates that the increasing trend is because more and more corporations adopting sustainability guidelines like GRI G4 and AA1000 principles.

Independent variables, executive compensation linked to sustainability performance and the total number of years of sustainability reporting, have a significant impact on the G100 scores at $90 \%$ and $99 \%$ confidence interval respectively. Good governance practices for sustainability performance are established by forming a link between executive compensation and sustainability performance. This variable has a significant impact for all 3 years on G100 scores, however, elimination of this variable did not show much change on the other variables and hence this variable was considered in our regression equation.

The average value of R-Square adjusted for three years is $38 \%$, which implies that these factors explained approximately 38\% variance in the sustainability performance of the G100 corporations. The regression equations for three years are as shown in Figure 10.

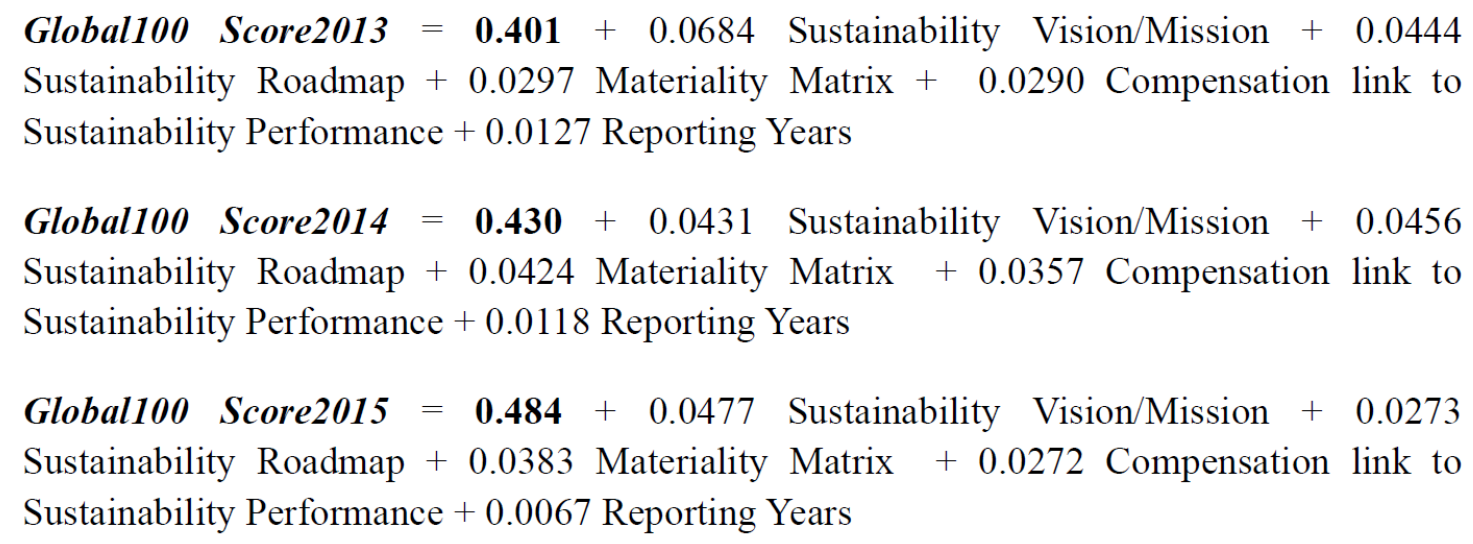

Figure 10. Regression equations' for the year 2013, 2014 and 2015 G100 corporations 


\section{Macrothink}

\subsection{Predictability of the Model}

Regression equation fit graphs are plotted to confirm the predictability of the model of this research. The regression scores of G100 corporations were plotted against the actual G100 scores with 90\% confidence interval for three consecutive years 2013, 2014 and 2015. The results of three years are as shown in Figures 11, 12 and 13. As shown in the Figure11 for the year 2013 more than $90 \%$ of the corporations were found to be in the prediction interval. Outliers with lower scores falling out of the predictable interface were observed to be mainly because there was no link between executive compensation and sustainability performance.

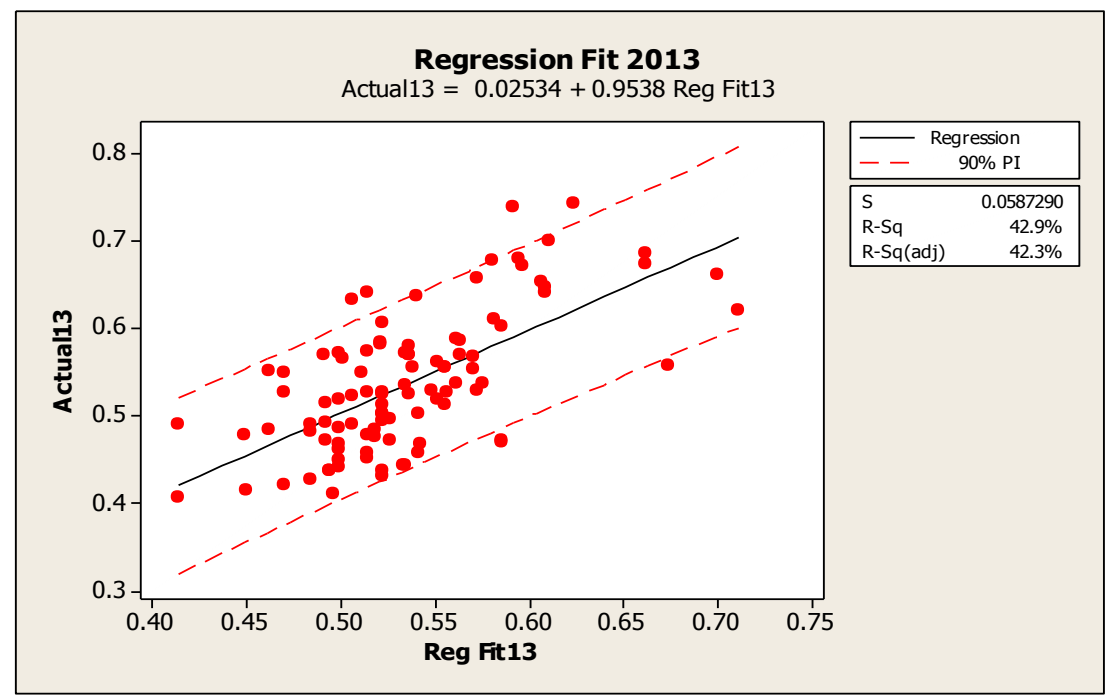

Figure 11. The regression fit graph of the year 2013 G100 corporations

As shown in Figure 14 for the year 2014 more than $90 \%$ of the corporations were found to be in the prediction interval. In this also outliers with lower scores falling out of the predictable interface were observed to be mainly because of missing link between executive compensation and sustainability performance.

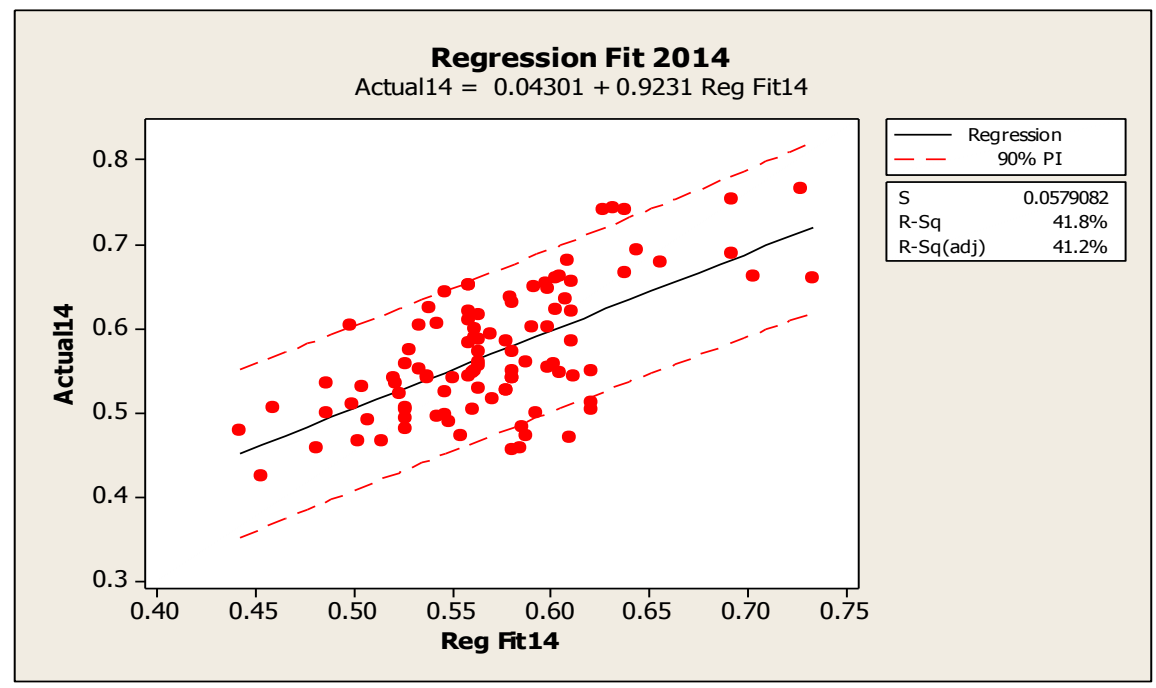

Figure 12. The regression fit graph of the year 2014 G100 corporations 


\section{Macrothink}

As shown in Figure 15 for the year 2015 also, more than $90 \%$ of the corporations were found to be in the prediction interval. Here we reconfirmed that outliers falling out of the predictable interface were observed to be mainly because of missing link between executive compensation and sustainability performance.

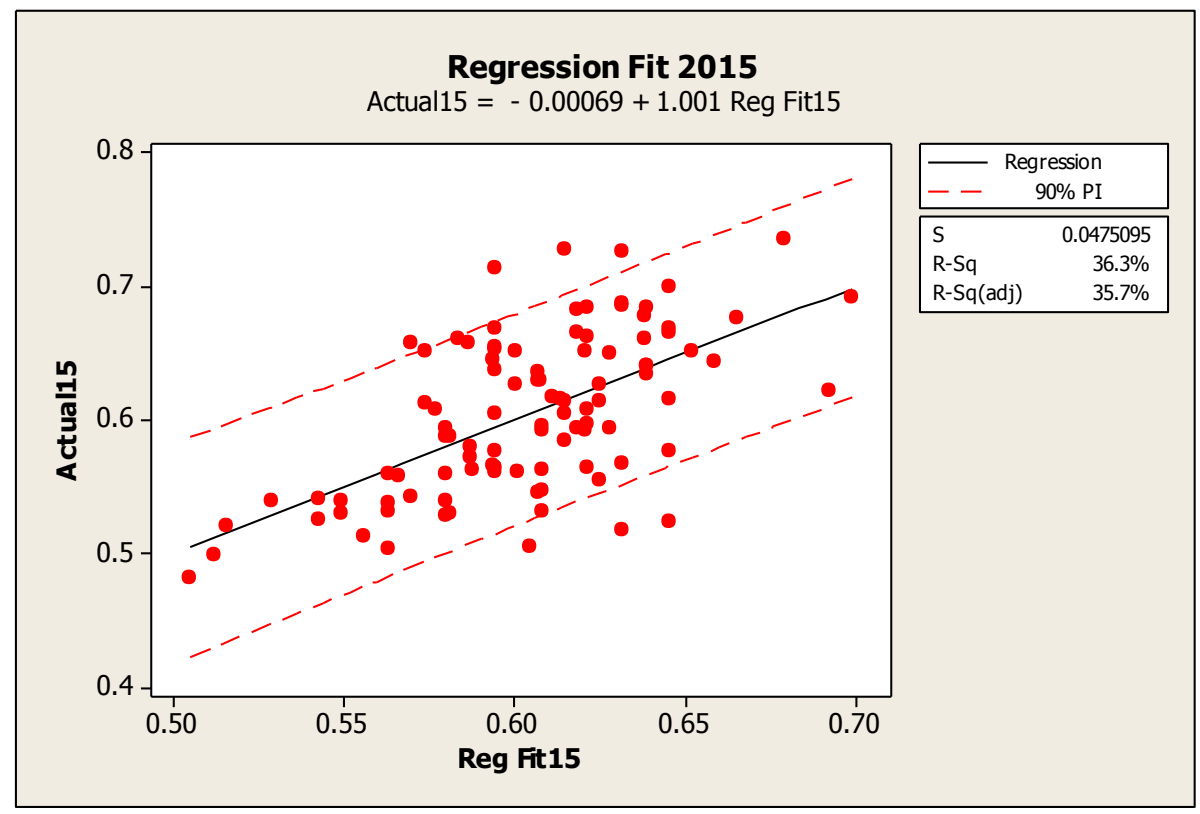

Figure 13. The regression fit graph of the year 2015 G100 corporations

The regression fit graph reassures the model predictability of superior sustainability performance and also confirms the research with more than $90 \%$ falling in the predictable interval at $90 \%$ confidence interval. With this, we can conclude that the chances of remaining corporations in the G100 index are higher for those with sustainable vision or mission statements, sustainability roadmaps, the materiality matrix, and a link between executive compensation and sustainability performance.

When we observe regression fit graphs of all the three consecutive years, it is apparent that the corporations falling out of predictable interface could get higher performance scores in any one year but could not sustain the score for all three years. The regression analysis of G100 corporations shows steady growth in the intercept for years 2013, 2014 and 2015. It indicates the average sustainability performance of the G100 corporations improved and it has set a higher benchmark. This is an indication, how global sustainability indices like G100 are contributing to overall sustainable development.

From T-Value $>1.96$ and P-Value $<0.05$, we can conclude that G100 corporations driving sustainability with sustainability vision or mission statements show a significant impact on superior sustainability performance. Hence corporations with only the economic growth addressed in their vision or mission statement can include social and environmental issues to make it holistic after discussing it with their stakeholders.

From T-Value $>1.96$ and P-Value $<0.05$, we can conclude that G100 corporations prioritizing their material issues and disclosing materiality matrix have higher chances of getting listed in 
G100 as compared to corporations without materiality matrix.

From the ' $\mathrm{T}$ ' and ' $\mathrm{P}$ ' values obtained, the sustainability roadmap shows a significant impact on sustainability performance. It confirms that internal management of sustainability practices based on a sustainability roadmap along with the integration and deployment of measures contributes to higher sustainability performance.

' $\mathrm{T}$ ' and ' $\mathrm{P}$ ' values obtained from the variable 'executive compensation link with sustainability performance' show a significant impact and which enables organizations to achieve better sustainability management.

It is a strategic position for sustainability when the classical distinction employed in management theory between internal and external drivers, its influence is extended by incorporating social and environmental factors and sustainability performance must become part of daily work of everyone within the organization. Structural Changes between 2013, 2014, 2015 - Confirmation with ' $Z$ ' Test. To understand the variation between years, the $Z$ test is conducted and results are seen in Table 4.

Table 4. Results of Z- test displaying Z-Value

\begin{tabular}{|l|l|l|l|}
\hline$Z$ - Test Result 'Z' Value <1.96> & $Z(13-14)$ & $Z(14-15)$ & $Z(13-15)$ \\
\hline Z - Sustainability Vision Mission & 7.89 & 0.77 & 3.34 \\
\hline Z - Sustainability Roadmap & 0.00 & 2.40 & 2.25 \\
\hline Z - Materiality Matrix & 7.18 & 0.85 & 1.69 \\
\hline Z - Executive Compensation link to Sustainability Performance & 0 & 1.38 & 0.31 \\
\hline Z - Sustainability Reporting Years & 0.52 & 2.02 & 1.96 \\
\hline
\end{tabular}

The Z- Value for vision/mission statements and materiality in the year 2013 is $>1.96$. The corporations adopted a social and environmental vision, mission statements as an objective and prioritized their materiality matrix exercise in the year 2013 as exhibited in Table 4.

Sustainability roadmaps and the number of years of reporting sustainability represent a significant shift in the year 2015 as compared with 2013, 2014, which means the number of corporations declaring their sustainability roadmap and sustainability reports is increasing with the progress of time. There is no significant change in the $Z$ value of the variable 'executive compensation link to sustainability performance' when two reporting years were compared. This means, on the whole, no major changes took place over these 3 years in the compensation structure of these corporations.

Z-Test ( $Z>1.96$ ) results of 2013 are different as compared to the results of 2014 and 2015. The changes in the policy and management practices for the integration of sustainability which happened during this year are reflecting the output of the Z-Test. With the help of the above study, it can be concluded that corporations need to assess their sustainability performance themselves to predict their being listed in G100 corporations.

The study provides insights into the influence of factors like sustainability roadmap, materiality matrix and adopting sustainability reporting practices, it is based on content quantification of G100. Using this approach, corporations may begin their sustainability programs with this approach or may improve their sustainability program by its application. 


\section{Conclusion}

Corporations may start a sustainability program with continual improvement projects in environmental and social performance however corporations with the following five conditions have comparatively higher chances of getting listed in G100 indices.

1. Clearly defined sustainability vision/mission statements

2. The future roadmap of the sustainability program

3. Stakeholder issues addressed in the form of the materiality matrix

4. Executive performance pay linked with sustainability performance

5. Sustainability report published with global guidelines

With the mentioned approach corporations can improve their sustainability performance and it will also help them to get listed repeatedly in the global sustainability indices.

Overall, Conclusion can be made that, globally the business sustainability is driven by the major investors. Global sustainability indices are directly helping investors in their decision making by rating corporations. Global sustainability indices will also help the world to achieve common sustainability agenda like SDG Sustainability) else portions to follow the path of sustainable development.

\section{Limitations}

The data generated is from a limited sample which represents the world's leading top 100 corporations; hence results can't be generalized for sustainability performance management of the entire industry. Conducting a similar sector wise study of such global sustainability ranking and indices could lead to construct a sustainable business model for each sector.

\section{References}

Baumgartner, R. J., \& Ebner, D. (2010). Corporate sustainability strategies: sustainability profiles and maturity levels. Sustainable Development, 18(2), 76-89.

https://doi.org/10.1002/sd.447

Bhattacharyya, S. S., Chaturvedi, A., \& Chaturvedi, A. (2009). A journey through the labyrinth of the business and society concepts. International Journal of Business Environment, 2(3), 281-306. https://doi.org/10.1504/IJBE.2009.023793

Bocken, N. M., Short, S. W., Rana, P., \& Evans, S. (2014). A literature and practice review to develop a sustainable business model archetypes. Journal of cleaner production, 65, 42-56. https://doi.org/10.1016/j.jclepro.2013.11.039

Coburn, C. E., Russell, J. L., Kaufman, J. H., \& Stein, M. K. (2012). Supporting sustainability: Teachers' advice networks and ambitious instructional reform. American Journal of Education, 119(1), 137-182. https://doi.org/10.1086/667699

Corporate Knights, (2017). The Magazine for clean capitalism. [Online] Available: http://www.corporateknights.com/reports/global-100

Ehrenfeld, J. R., \& Hoffman, A. J. (2013). Flourishing: A frank conversation about 
sustainability. Stanford University Press.

Fortune Global 500, (2017). The worlds' 500 largest companies. [Online] Available: http://fortune.com/global500

FTSE4Good Index Series (2016). FTSE Russell. [Online] Available:

https://www.ftse.com/products/indices/ftse4good

Gibson, K. (2012). Stakeholders and sustainability: An evolving theory. Journal of Business Ethics, 109(1), 15-25. https://doi.org/10.1007/s10551-012-1376-5

Global Reporting Initiative, GRI. (2016). Empowering Sustainable Decisions. [Online] Available: https://www.globalreporting.org/Pages/default.aspx

Happy Planet Index (2017). Measures what matters, Sustainable wellbeing for all (Online) Available http://happyplanetindex.org

Hart, S. L., \& Milstein, M. B. (2003). Creating sustainable value. Academy of Management Perspectives, 17(2), 56-67. https://doi.org/10.5465/ame.2003.10025194

Helliwell, J. F., Layard, R., \& Sachs, J. (2012). World happiness report.

Helliwell, J. F., Huang, H., \& Wang, S. (2015). The geography of world happiness. World happiness report, 2015, 12-41.

Hsu, C. W., Lee, W. H., \& Chao, W. C. (2013). Materiality analysis model in sustainability reporting: a case study at Lite-On Technology Corporation. Journal of cleaner production, 57, 142-151. https://doi.org/10.1016/j.jclepro.2013.05.040

Integrated Reporting (2016). The international integrated reporting framework. [Online] Available: http://integratedreporting.org/resource/international-ir-framework

ISO 26000 Social responsibility (2016). [Online] Available:

https://www.iso.org/iso-26000-social-responsibility.html

Joseph, C., \& Taplin, R. (2011, March). The measurement of sustainability disclosure: Abundance versus occurrence. Accounting Forum, 35(1), 19-31.

https://doi.org/10.1016/j.accfor.2010.11.002

López, M. V., Garcia, A., \& Rodriguez, L. (2007). Sustainable development and corporate performance: A study based on the Dow Jones sustainability index. Journal of Business Ethics, 75(3), 285-300. https://doi.org/10.1007/s10551-006-9253-8

Okumuş, G., \& Edelman, D. J. (2015). An Indicator Model of the Spatial Quantification and Pattern Analysis of Urban Sustainability: A Case Study of Cincinnati, Ohio. Current Urban Studies, 3(03), 231. https://doi.org/10.4236/cus.2015.33019

O'Riordan, L., \& Fairbrass, J. (2008). CSR-Theories, models and concepts in stakeholder dialogue-A model for decision-makers in the pharmaceutical industry. Journal of Business Ethics, 83(4), 754-758. https://doi.org/10.1007/s10551-008-9662-y 


\section{Macrothink}

Environmental Management and Sustainable Development

ISSN 2164-7682

2019, Vol. 8, No. 2

Osterwalder, A., \& Pigneur, Y. (2010). Business model generation: a handbook for visionaries, game changers, and challenges. John Wiley \& Sons.

Siew, R. Y. J. (2014). Evaluating and enhancing the impact of sustainability reporting tools (SRTs) (Doctoral dissertation, Ph. D. thesis, School of Civil and Environmental Engineering, University of New South Wales, Sydney).

SA8000 Standard (2017). Social Accountability International. [Online] Available:

http://sa-intl.org/index.cfm?fuseaction=Page.ViewPage\&pageId=1929

Standards (2017). Accountability AA1000. [Online] Available:

https://www.accountability.org/standards

Stead, J. G., \& Stead, W. E. (2014). Sustainable strategic management. Routledge. https://doi.org/10.4324/9781315700533

Stubbs, W., \& Cocklin, C. (2008). Conceptualizing a "sustainability business model". Organization \& Environment, 21(2), 103-127. https://doi.org/10.1177/1086026608318042

Sustainability Accounting Standard Board (2017). SASB. [Online] Available:

https://www.sasb.org

United Nations Development Programme. (2018). Sustainable development goals. [Online] Available: https://www.undp.org/content/undp/en/home/sustainable-development-goals.html

UNEP, C., \& IUCN, T. (2013). Elephants in the dust-the African elephant crisis. A rapid response assessment. [Online] Available: http://wedocs.unep.org/handle/20.500.11822/8539

Zott, C., Amit, R., \& Massa, L. (2011). The business model: recent developments and future research. Journal of management, 37(4), 1019-1042.

https://doi.org/10.1177/0149206311406265

\section{Glossary}

AA1000 AccourntAbility Stakeholder Engagement Standards

CDP Carbon disclosure project

DJSI Dow Jones sustainability indices

ESG Environment, social and governance

FTSE4GOOD Financial times stock exchange, Russell ESG index

G100 Global most sustainable 100 corporations

GRI Global Reporting Initiative

GHG Greenhouse gas

HPI Happy planet index

ISO International Organisation of Standards 
MSA Media stakeholder analysis

SDG Sustainable development goals

SE Standard Error

\section{Copyright Disclaimer}

Copyright for this article is retained by the author(s), with first publication rights granted to the journal.

This is an open-access article distributed under the terms and conditions of the Creative Commons Attribution license (http://creativecommons.org/licenses/by/3.0/). 